\title{
ADOLESCENT IDIOPATHIC SCOLIOSIS AND SIMILAR CONDITIONS: SHORT, APICAL, SINGLE OR MULTIPLE FIXATION
}

\author{
ESCOLIOSE IDIOPÁTICA DO ADOLESCENTE E SIMILARES: FIXAÇÃO CURTA, APICAL, \\ ÚNICA OU MÚLTIPLA
}

\section{ESCOLIOSIS IDIOPÁTICA DEL ADOLESCENTE Y AFECCIONES SIMILARES: FIJACIÓN CORTA, APICAL, ÚNICA O MÚLTIPLE}

Enguer Beraldo Garcia, ${ }^{1,2}$ Liliane Faria Garcia, ${ }^{1,2}$ Enguer Beraldo Garcia Jr, ${ }^{2}$ Juliana Garcia Camarinha, ${ }^{2}$ Marcos Felipe Camainha, ${ }^{2}$ Roberto Garcia Gonçalves, ${ }^{1}$ Eduardo Beraldo Garcia, ${ }^{1}$ Saulo Terror Giesbrecht, ${ }^{1}$ Victor de Oliveira Matos ${ }^{1}$

1. Spine Group of Santa Casa de Belo Horizonte, MG, Brazil.

2. Institute of the Vertebral Column of Belo Horizonte, Belo Horizonte, MG, Brazil.

\begin{abstract}
Objective: To create a new instrumentation principle for the treatment of adolescent idiopathic scoliosis (AIS) and similar conditions. Methods: A new fixation format was created for the treatment of AIS using 3rd generation instrumentation in short, apical and single or multiple fixations. In patients presenting one scoliotic curve, one fixation is performed. In patients with two curves, two fixations are performed, and in those with three curves, three fixations are performed. To evaluate the new method, a retrospective study of 54 patients who had already undergone surgery for AIS and similar conditions using this innovation was conducted. Results: In this series, average corrections of $72 \%$ in the proximal curve, of $83 \%$ in the thoracic curve, and of $85 \%$ in the thoracolumbar curve were verified. Conclusions: It was concluded that the new fixation principle in the treatment of AIS and similar conditions using short, apical and multiple fixations presented excellent correction, better still in the curves that were more distal in relation to the spine. There was a significant statistical difference between the percentages of curvature correction. Level of Evidence III; Retrospective study.
\end{abstract}

Keywords: Scoliosis; Preoperative care; Postoperative care; Adolescent.

RESUMO

Objetivo: Criar um novo princípio de instrumentação no tratamento da escoliose idiopática do adolescente (EIA) e similares. Métodos: Criou-se uma nova formatação de fixação no tratamento da EIA, usando-se instrumental de terceira geração, empregando-se fixações curtas, apicais, únicas ou múltiplas. Paciente apresentando uma curva escoliótica, realizou-se uma fixação, com duas curvas, duas fixações e três curvas, fez-se três fixações. Para avaliar o novo método, realizou-se um estudo retrospectivo de 54 pacientes já operados de EIA e Similares com a referida inovação. Resultado: Nessa casuística, constatou-se uma correção média de $72 \%$ na curva proximal, correção de $83 \%$ na curva torácica média e $85 \%$ na curva toracolombar. Conclusão: Concluiu-se que o novo princípio de fixação no tratamento da ElA e Similares, empregando fixações curtas, apicais e múltiplas, apresentou-se excelente correção, melhor ainda nas curvaturas mais distais em relação à coluna. Existe diferença estatística entre os percentuais de correção das curvaturas entre o pré e pós operatório. Nível de Evidência III; Retrospectivo.

Descritores: Escoliose; Cuidos pré-operatórios; Cuidados pós-operatórios; Adolescente.

\section{RESUMEN}

Objetivo: Crear un nuevo principio de instrumentación para el tratamiento de la escoliosis idiopática del adolescente (EIA) y afecciones similares. Métodos: Se creó un nuevo formato de fijación en el tratamiento de la ElA, utilizando instrumentos de $3^{a}$ generación, en fijaciones cortas, apicales y únicas o múltiples. En pacientes que presentan una curva escoliótica, se realiza una fijación. En pacientes con dos curvas, se realizan dos fijaciones y en aquellos con tres curvas, se realizan tres fijaciones. Para evaluar el nuevo método, se realizó un estudio retrospectivo de 54 pacientes ya operados para corrección de ElA y afecciones similares utilizando esta innovación. Resultados: En esta casuística, se verificaron correcciones promedio del $72 \%$ en la curva proximal, corrección del 83\% en la curva torácica media y del 85\% en la curva toracolumbar. Conclusiones: Se concluyó que el nuevo principio de fijación en el tratamiento de la ElA y afecciones similares con fijaciones cortas, apicales y múltiples presentó una excelente corrección, mejor aún en las curvas más distales en relación con la columna vertebral. Hubo una diferencia estadística significativa entre los porcentajes de corrección de las curvaturas. Nivel de Evidencia III; Estudio retrospectivo.

Descriptores: Escoliosis; Cuidados preoperatorios; Cuidados posoperatorios; Adolescente. 


\section{INTRODUCTION}

Scoliosis is defined as a deviation of the spine in the coronal and horizontal planes. ${ }^{1}$ Idiopathic scoliosis is the most commonly encountered spinal deviation of unknown etiology. ${ }^{2}$

The development of implants in spine surgery has enabled the surgical treatment of these deformities by means of more selective correction, such that only the vertebrae that present the most intense morphological changes are included in the area of the arthrodesis. The use of this more selective fixation and arthrodesis method permits correction of the deformity by means of shorter arthrodeses, preserving spinal segments. This treatment approach restores spinal alignment, allowing greater flexibility as compared to the classical correction techniques for this deformity. ${ }^{3,4}$

The authors of this article also created a new Three-Dimensional Classification for adolescent idiopathic scoliosis (AIS) and similar conditions. It has three components: the "quantitative factor" that divides the format of the deformity into basic types, the "locator factor" that defines the site of the principal curve, and the "sagittal factor" that shows the reality of the overall sagittal plane, from $\mathrm{C} 1$ to $\mathrm{S} 1 .^{5}$

The Cobb method measures the amplitude of the curve and calculates the angle by drawing two lines, one tangent to the upper terminal plate of the cranial vertebra and one tangent to the lower terminal plate of the caudal vertebra, from each of which a perpendicular line is drawn, and the intersection of these two lines forms the angle to be measured, making the measurement of each curve possible. ${ }^{6}$

We created a new tool called the Sacral Clavicular Angle (SCA) to measure the overall coronal plane of the spine and provide us with the real balance of this plane, an indispensable factor in the correction of scoliosis. To measure the SCA, a line is drawn parallel to the base of the sacrum and a second line is drawn from the center of and perpendicular to the first for the entire extension of the spine. A third line is drawn passing through the intersections of the superior portions of the clavicles with the second ribs, thus forming two angles, which measure $90^{\circ}$ by $90^{\circ}$ in non-scoliotic people. The standard established was to measure the greater angle on the side exceeding $90^{\circ}$ with the goniometer and the SCA value was defined as the number of degrees in excess of $90^{\circ}$.

The objective of this study was to present a new principle for the fixation of AIS and similar conditions, with short, apical, and multiple fixations and to evaluate the results of the correction.

\section{METHODS}

The project was submitted by the Santa Casa de Belo Horizonte on 05/17/17 and approved as CAAE 68440217.3.0000.5138. The study participants signed the Informed Consent Form.

The Spine Groups of the Instituto da Coluna Vertebral and of the Orthopedics and Traumatology Service of the Santa Casa, both located in Belo Horizonte, introduced a new instrumentation principle for the surgical treatment of AIS and similar conditions. It was established that in the case of scoliosis with one curve one fixation would be performed, with two curves two fixations would be performed, and with three curves three fixations would be performed. Accesses would be specific, trying to fix the least possible number of vertebrae and provide coronal plane balance.

The ideology of the new principle is to precisely identify the apex of the curve, considered "the soul" of the deformity, and focus the instrumentation, which should be short and apical, and may be single or multiple in cases with more than one structural curve, there.

The criteria for inclusion of vertebrae were applied to panoramic $X$-rays of the spine in PA with forced right and left inclination: In correction from 75 to 90\%: Fix 2 apical vertebrae. Correction from 50 to 74\%: Fix 2 to 3 vertebrae. Correction from 25 to 49\%: Fix 4 to 5 vertebrae. Correction from 0 to 24\%: Fix all extension of the curve, study the possibility of not fixing terminal vertebrae. Always considering the peculiarity of each curve, depending on the location, rotation, rigidity, extension, and skeletal maturity.

Third generation instrumentation was used combined with arthrodeses with short and apical, single or multiple transpedicle fixations. The screws were placed in the apex of the curve. The expectation was for the least number of fixations, especially in the lumbar region. Well centered screws were used, with the thickness and length depending on the size of the pedicle. Two rods were cut to lengths in accordance with the number of curves, fixed, and the system was adjusted. See Figure 1.

Evoked potential monitoring of the spinal cord and nerve roots was used.

To test the new fixation and correction principle, a retrospective study of 54 patients with AIS and similar conditions, already operated by the authors using the referenced innovation, was conducted. The 15 most recently operated cases were excluded.

The evaluators used the medical report data and the radiological images of the patients, consisting of pre- and postoperative panoramic X-rays of the spine in PA and lateral views in the standing position.

The variables collected were sex, age, race, the $\mathrm{SCA}^{7}$ measured, and using the Cobb method, ${ }^{6}$ the angles of the proximal curve located from the cervical to $T 5$, of the middle thoracic curve from $\mathrm{T} 6$ to $\mathrm{T} 10$, and the thoracolumbar curve from $\mathrm{T} 11$ to $\mathrm{S} 1^{5}$ in order to analyze and compare the corrections of the curvature between the pre-and postoperative periods.

The data obtained were submitted to biostatistical analysis. First, an exploratory analysis was conducted using frequency distribution for the demographic and clinical variables in order to characterize the patient sample.

The non-parametric Wilcoxon test was used to assess the differences between the pre- and postoperative Cobb values of the study patients.

For the comparison of the proximal $(A)$, middle thoracic $(B)$, and thoracolumbar $(C)$ curves of the Three-Dimensional Classification ${ }^{5}$ in terms of the percentage of reduction from the pre- to postoperative Cobb angle measurements, the ANOVA parametric test was used.

The study data were processed in the PASW version 18 statistical program. A significance level of $5 \%$ was used in all the statistical tests performed. Thus, associations were considered statistically significant when the $p$ value was less than $0.05^{8}$

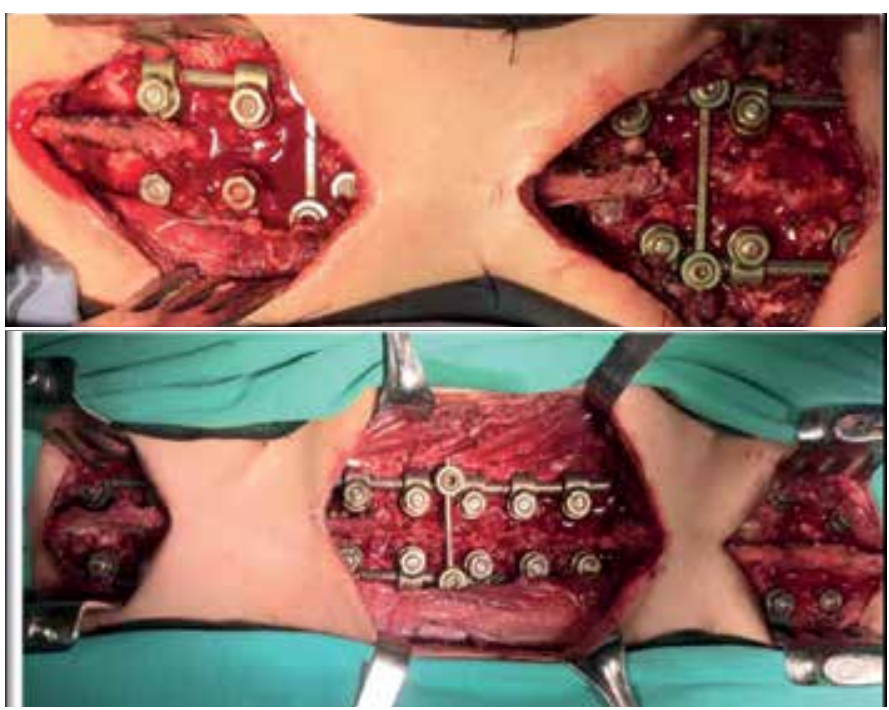

Figure 1. Surgical treatment of AIS with short, apical, and multiple fixations. The photograph above shows a case with two scoliotic curves and two fixations. The photo below is of a patient with three curves and three fixations.

\section{RESULTS}

The mean age of the patients was 15.5 years with a standard deviation of 4.3 years, with a minimum age of 9 and a maximum age of 38 years. They were predominantly White (92.6\%) and female (94.4\%).

Table 1 shows that in the total sample the median pre-operative Cobb angle of the proximal curve was $30.0^{\circ}$, while the postoperative median was $9^{\circ}$. A comparison of these two moments yields a reduction 
of approximately $70 \%$ in the postoperative Cobb in relation to the preoperative value. This difference between the pre- and postoperative angles was confirmed as statistically significant by the statistical test.

Also, Table 1 shows a median preoperative Cobb value for the middle thoracic curve of $50.0^{\circ}$, while the postoperative median was $9^{\circ}$. Comparing these two moments, there was a reduction of approximately $82 \%$ in the postoperative Cobb angle in relation to the preoperative value. This difference between the pre- and postoperative angles was confirmed as statistically significant by the statistical test.

Continuing with Table 1, there was a large median preoperative Cobb angle of $42.0^{\circ}$ for the thoracolumbar curve, while the postoperative angle was $5^{\circ}$. A comparison of these two moments yields a reduction of approximately $88 \%$ in the postoperative Cobb in relation to the preoperative value. This difference between the pre- and postoperative angles was confirmed as statistically significant by the statistical test.

According to the ANOVA results in Table 2 and Figure 2 , there is a statistical difference between the percentage of reduction of the proximal, middle thoracic, and thoracolumbar curves.

By means of the confidence interval calculated in Table 3, it can be said that the middle thoracic and thoracolumbar curves had the same amount of reduction ( $83 \%$ and $85 \%$, respectively). However, the proximal curve had a smaller amount of reduction of the angle (72\%). Figure 2

Examples of the cases in this series, measuring the Cobb and SCA angles in the pre- and postoperative periods, and showing the degrees of correction

\section{DISCUSSION}

The advances of new types of instrumentation in AIS have made greater corrections of deformities possible. With selective arthrodeses, in which instrumentation is only implemented in the main thoracic curve, curves classified as King Type II and Lenke $2 \mathrm{CN}^{8,9}$ involve a smaller number of vertebrae in the arthrodesis, enabling greater mobility and less surgical time and risk. ${ }^{9-11}$

The goal of curve correction was achieved with the use of 3rd generation instrumentation, but in several studies the presence of decompensation of the trunk was observed after 1 year of follow-up. ${ }^{11-14}$

The patient with thoracic scoliosis has have perfect balance of the head over the pelvis without decompensation of the trunk. ${ }^{12}$ However, if the same individual has a large thoracic curve, the trunk may be significantly displaced far from the midline of the pelvis, reflecting a marked decompensation in the position of the thorax over the pelvis. ${ }^{11,13}$

In almost 18 years treating AIS with short and selective fixations with 3rd generation instrumentation, trying to preserve vertebral mobility, it has been possible to observe patients with visible asymmetry of the shoulders with a certain frequency.

In agreement with the literature, ${ }^{15-17}$ quality 3rd generation instrumentation truly was the differential in the treatment of AIS. However, selective instrumentation can bring imbalance to the coronal plane, mainly when we do not treat the secondary structural curves or when we interrupt the instrumentation at the apex of these curves. Secondary structural curves cause trunk imbalance, especially when the main curve is completely corrected.

This situation led us to think about solutions and we started to
Table 2. Analysis of Variance (ANOVA) for the proximal, middle thoracic and thoracolumbar curves in relation to the percentage of angle reduction.

\begin{tabular}{c|c|c|c|c|c}
\hline $\begin{array}{c}\text { Source of } \\
\text { Variation }\end{array}$ & $\begin{array}{c}\text { Degrees of } \\
\text { Freedom }\end{array}$ & $\begin{array}{c}\text { Sum of } \\
\text { Squares }\end{array}$ & $\begin{array}{c}\text { Mean } \\
\text { Square }\end{array}$ & F-Value & P-Value \\
\hline $\begin{array}{c}\text { Between the } \\
\text { methods }\end{array}$ & 2 & 2721 & 1360.7 & 12.4 & $p<0.001^{* *}$ \\
\hline Residual & 112 & 12286 & 109.7 & & \\
\hline Total & 114 & 15007 & & & \\
\hline
\end{tabular}

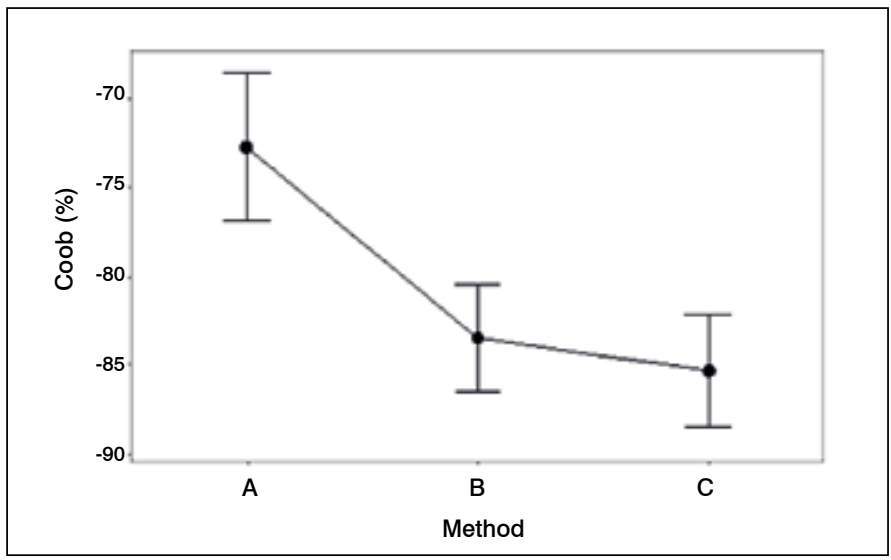

Figure 2. Confidence interval of the percentage of reduction of the proximal, middle thoracic, and thoracolumbar curves.

Table 3. Confidence interval of the percentage of angle reduction for the proximal, middle thoracic, and thoracolumbar curves.

\begin{tabular}{c|c|c|c|c|c}
\hline Curve & N & Mean (\%) & S.D. (\%) & \multicolumn{2}{|c}{ Cl 95\% } \\
\hline Proximal & 25 & -72.71 & 13.53 & $(-76.86 ;$ & $-68.56)$ \\
\hline Middle thoracic & 46 & -83.43 & 9.06 & $(-86.49 ;$ & $-80.37)$ \\
\hline Thoracolumbar & 44 & -85.28 & 9.88 & $(-88.41 ;$ & $-82.15)$ \\
\hline
\end{tabular}

aim towards the execution of short, apical, and multiple fixations, but since we had no support from the literature, we always gave up on the project.

Only at the beginning of 2014 did we finally operate for the first time on a patient with three curves, performing three approaches with three fixations, with excellent results today after 54 months of follow-up.

We believe that with the creation of the Third Generation Instrumental, with the diversity of force to be applied, depending on the positioning of the transpedicular screws in the column, its application to the column also needs a new formatting, being what we did.

The ideology of the new principle for the treatment of AIS and similar conditions is to precisely identify the apex of the curve, considered "the soul" of the deformity. Panoramic radiographs in PA with forced right and left inclination are of fundamental importance in defining the apex and the vertebrae to be included.

The fixation, which should be short, is focused on the apex and there may be multiples in cases with more than one structural curve. The peculiarities of each curve must be taken into account, including location, rotation, rigidity, extension, and skeletal maturity.

Table 1. Frequency distribution of the 54 patients by preoperative and postoperative periods.

\begin{tabular}{|c|c|c|c|c|c|c|c|c|}
\hline \multirow{2}{*}{ Clinical Variable } & \multirow{2}{*}{ Group } & \multicolumn{5}{|c|}{ Descriptive Measurements } & \multicolumn{2}{|c|}{ P-value } \\
\hline & & $\mathbf{n}$ & Mean & S.D. & P25 & Median & P75 & \\
\hline \multirow{2}{*}{ Cobb $\left({ }^{\circ}\right)$} & Pre-op proximal curve $\left(^{\circ}\right)$ & 25 & 30.60 & 9.60 & 24.00 & 30.00 & 39.50 & $\mathrm{p}<0.001 * *$ \\
\hline & Post-op proximal curve $\left({ }^{\circ}\right)$ & 25 & 7.80 & 3.50 & 5.50 & 9.00 & 10.00 & \\
\hline Cobb $\left({ }^{\circ}\right)$ & Post-op middle thoracic curve $\left({ }^{\circ}\right)$ & 47 & 9.09 & 7.76 & 5.00 & 9.00 & 11.00 & \\
\hline Cobb $\left({ }^{\circ}\right)$ & Pre-op thoracolumbar curve $\left({ }^{\circ}\right)$ & 44 & 44.48 & 9.30 & 40.00 & 42.00 & 48.75 & $\mathrm{p}<0.001^{* *}$ \\
\hline
\end{tabular}

The probabilities of significance (p-values) refer to the Wilcoxon test. Curve (C). 
In fixations of only two vertebrae, the four screws should be long, thick, and well positioned in the pedicle and the vertebral body, seeking the highest possible degree of stability, especially in the lumbar region where the spine is generally more mobile. Therefore, the preservation of the supra and infraspinous ligaments and the implant of the transverse device seem to be fundamental.

In this case series there was a mean correction in the proximal curve of $72 \%$, in the thoracic curve of $83 \%$, and in the thoracolumbar curve of $85 \%$. (Figures 3 to 9) These corrections are similar to those reported in traditional fixations, however, the traditional method does not have the advantages mentioned above.

Of the 54 cases of AIS and similar conditions treated, five were older than 17 years of age. All responded well to the new principle of instrumentation. The average follow-up of the case series was 16.5 months.

The authors live a learning curve, now with 88 cases operated with short, apical and multiple fixations, which has been solidifying and to which they have added experience with approaches to one 9 -year old patient and another who was 38 years of age. We believe that a longer follow-up is essential.

We emphasize that in cases of severe scoliosis above $90^{\circ}$ and severe and rigid kyphosis, multiple fixation should not be indicated.

Considering kyphoscoliosis, the kyphotic component with some mobility, in the growth phase, with Risser from one to two, can be corrected previously with the Milwaukee vest and later the multiple fixation is applied to correct scoliosis.

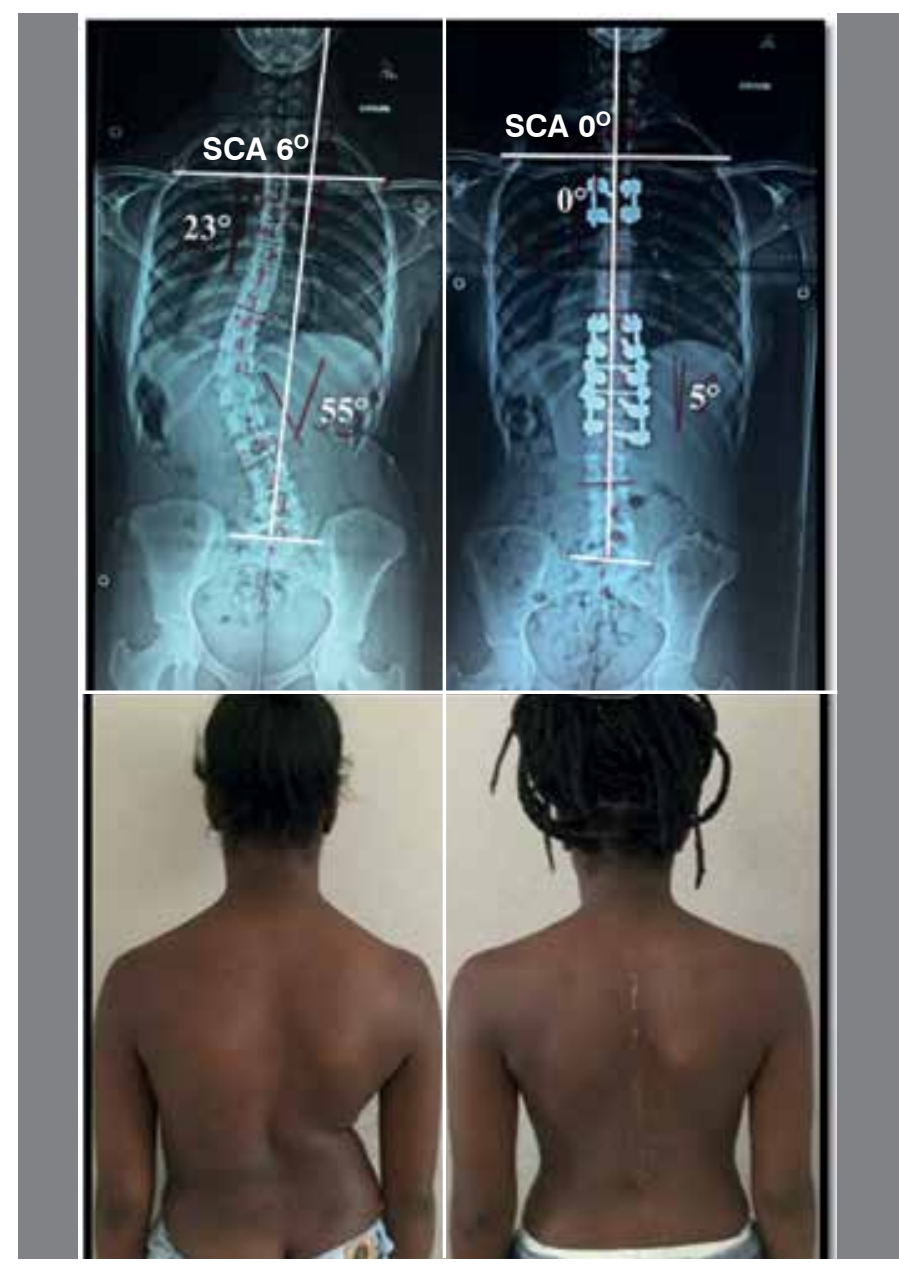

Figure 3. Patient with AIS, 13 years of age, female, presenting two scoliotic curves submitted to two short and apical fixations. On the upper left is the preoperative radiography with the Cobb angle and SCA measurements. On the upper right, the image shows the angle reductions. On the lower left, is a photo of the patient prior to surgery and on the lower right, after correction. Note the balance of the shoulders.

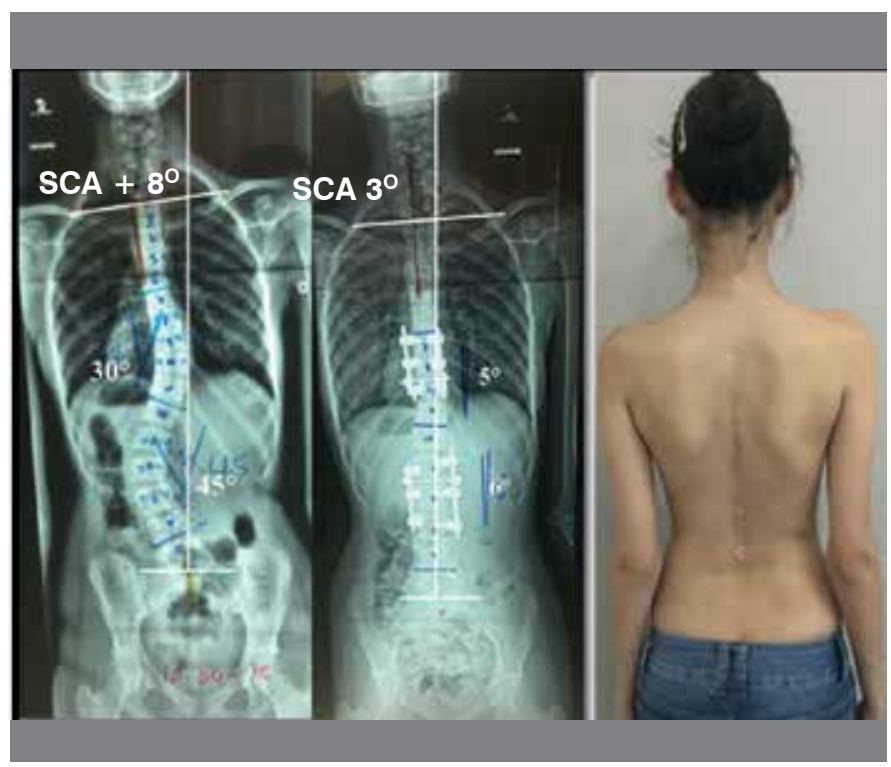

Figure 4. Patient, 13 years of age, female, with AIS with 2 curves submitted to two short, apical fixations. On the left, the preoperative radiograph shows the measurements of the Cobb angle and SCA. The center $X$-ray shows the reductions of the angles. On the right, a photo following surgery.

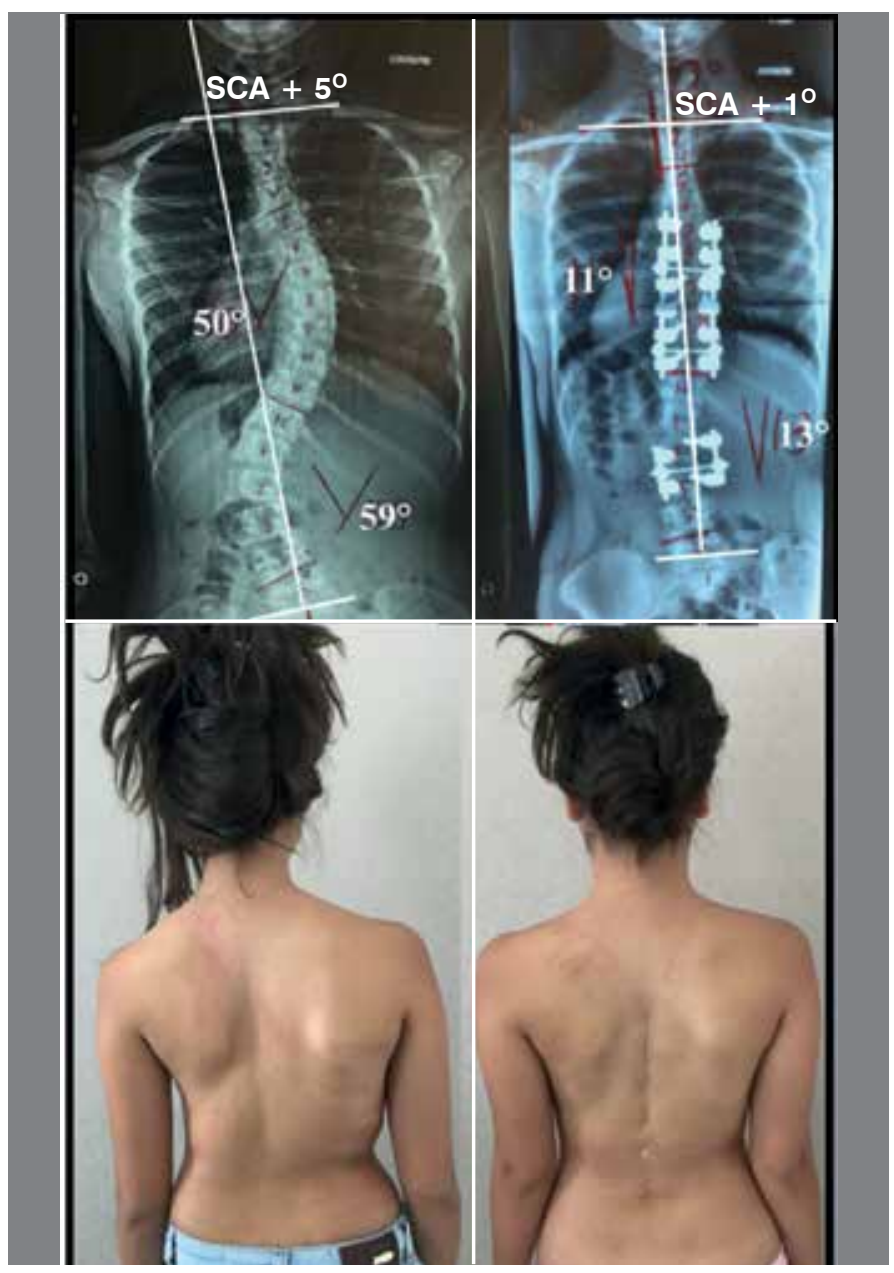

Figure 5. Patient, 13 years of age, female, with AIS presenting 2 curves submitted to two short, apical fixations. The upper left is a radiograph showing the measurements of the Cobb angle and SCA and on the upper right, the reductions of the angles can be seen. On the lower left is a preoperative photograph of the patient and on the right, following correction. Note the balance of the trunk. 

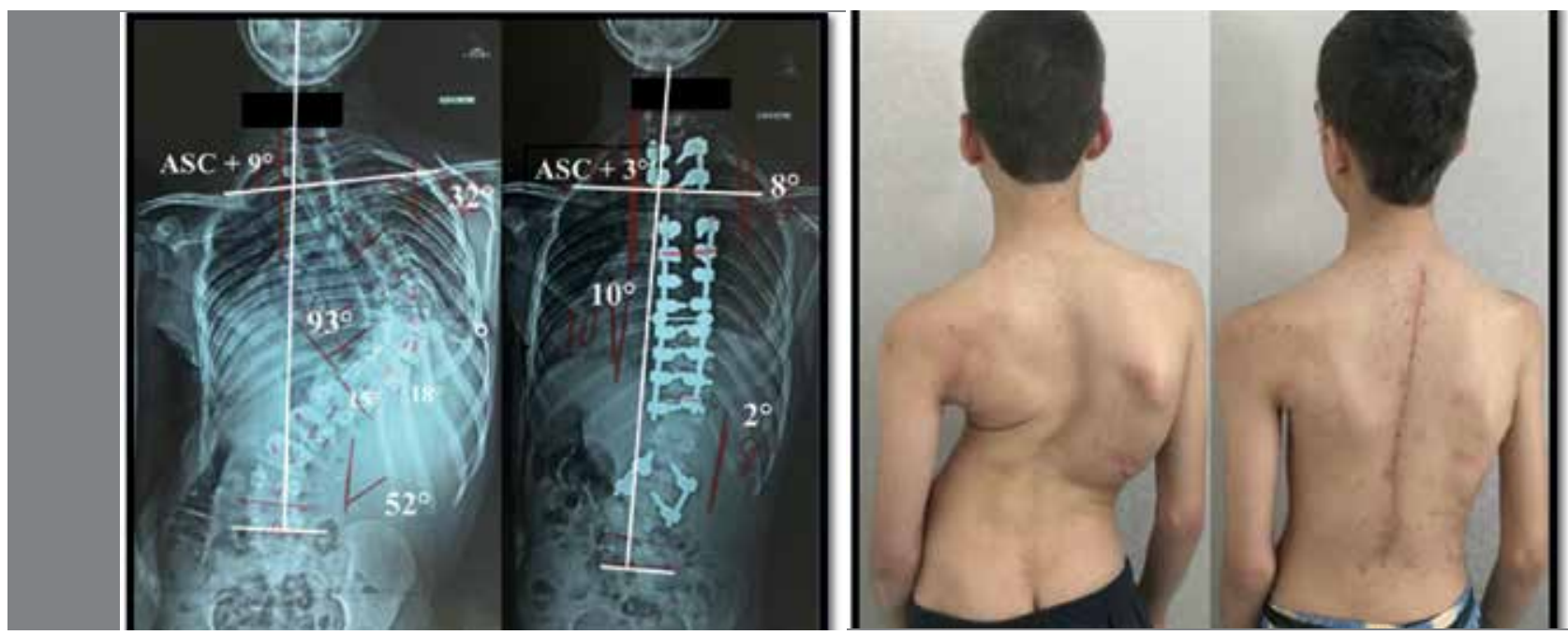

Figure 6. Patient, 14 years old, male, with a severe case of evolutive AIS with the trunk imbalanced to the right, an SCA of $+9^{\circ}$, presenting 3 curves, submitted to short, apical and multiple fixations. On the upper left, the radiograph shows high Cobb angle and SCA values. On the right, an X-ray shows the reduction in the angles. On the lower left, a preoperative photo of the patient and on the right of the results of the correction.

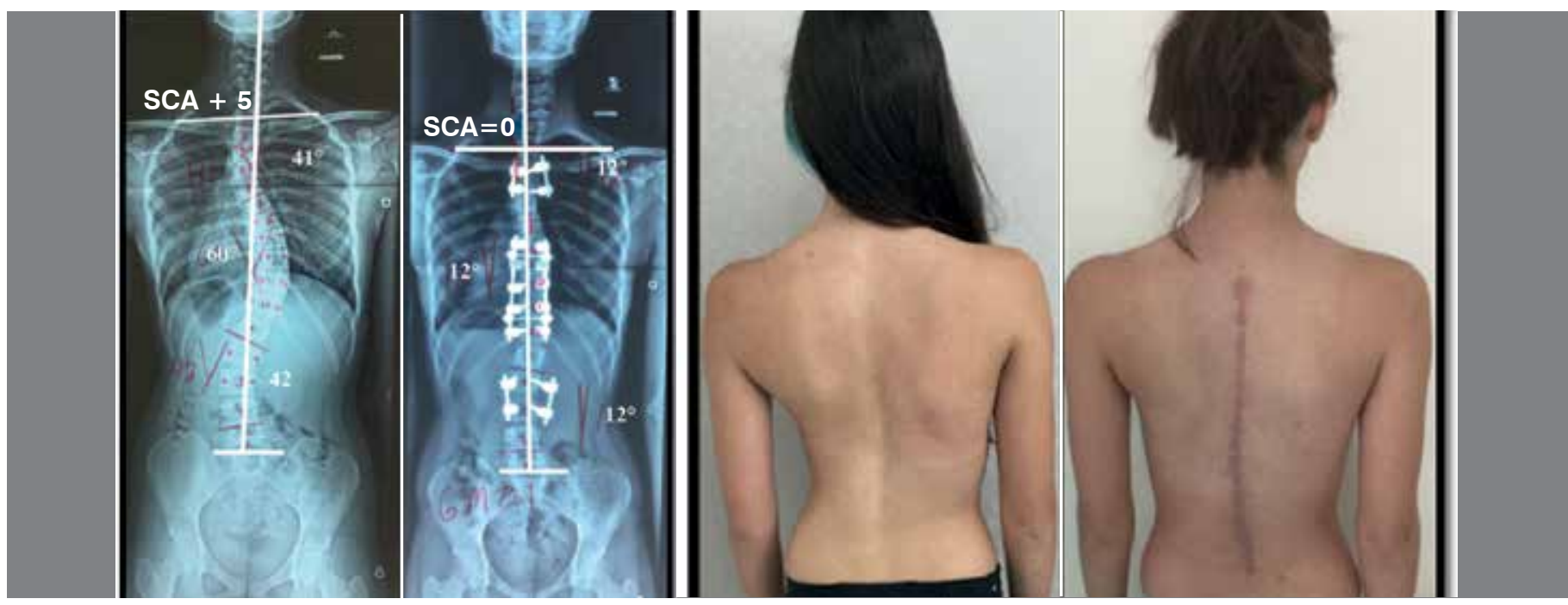

Figure 7. Patient, 13 years of age, female, with AIS with 3 curves affecting the entire extension of the thoracolumbar spine, submitted to short, apical and multiple fixations. On the upper left the X-ray with the Cobb angle and SCA measurements can be seen. The upper right image shows the angle reductions. On the lower left is the preoperative photograph and on the right the results of the correction are shown

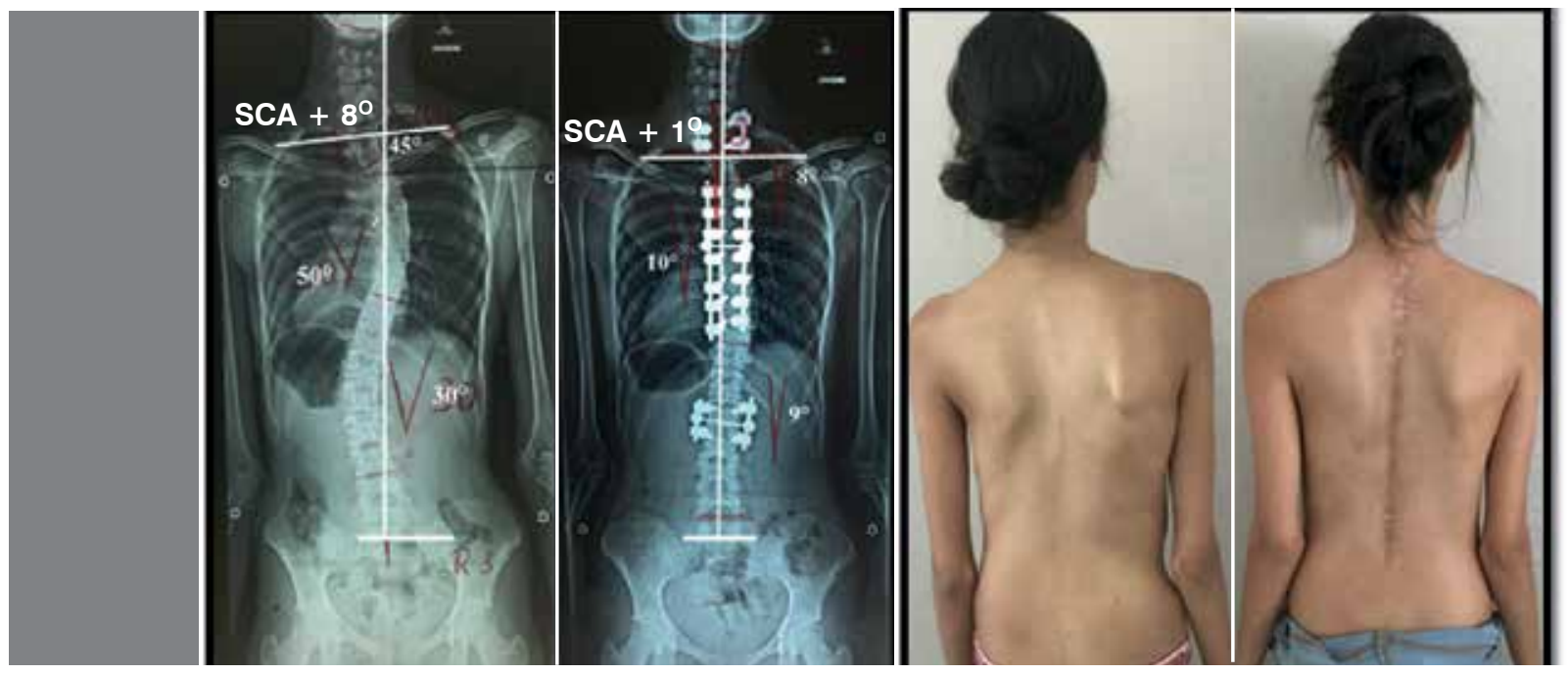

Figure 8. Patient, 13 years of age, female, with AIS with 3 curves affecting the entire extension of the thoracolumbar spine, submitted to short, apical and multiple fixations. On the upper left the X-ray with the Cobb angle and SCA measurements can be seen. The upper right image shows the angle reductions. On the lower left is the preoperative photograph and on the right the results of the correction are shown. 

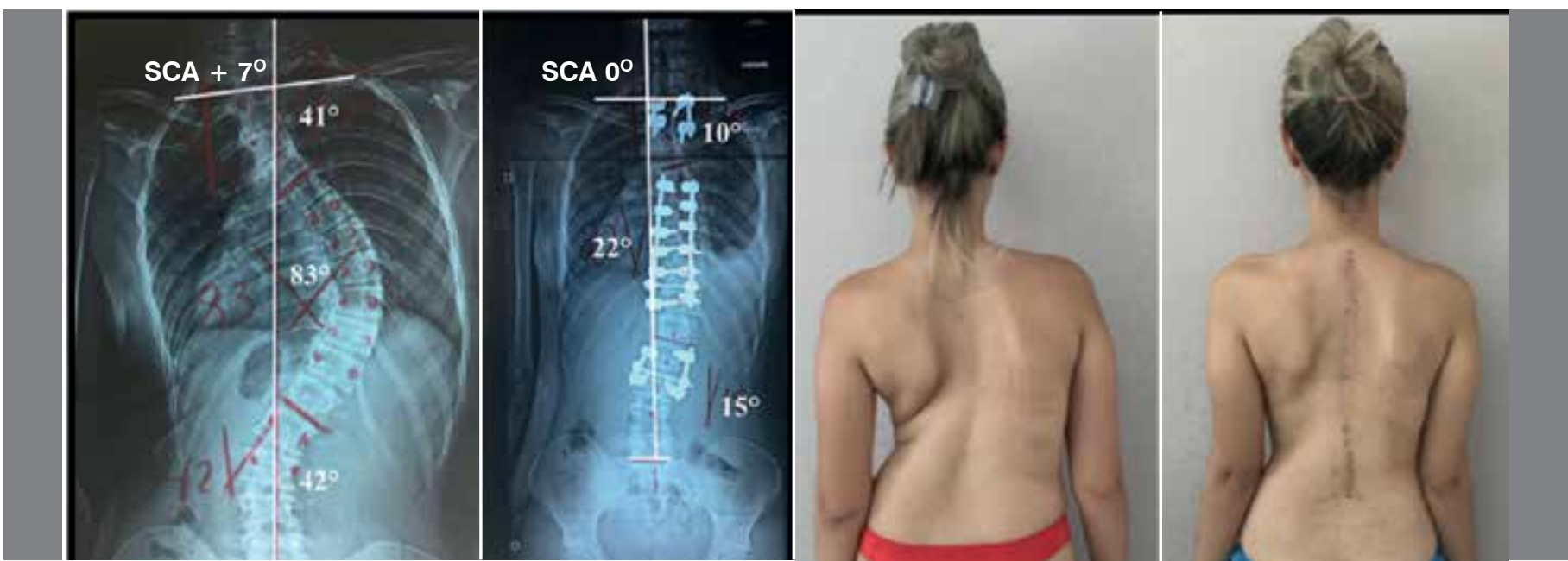

Figure 9. Patient, 14 years of age, female, with AIS presenting severe, rigid curves, submitted to three short, apical fixations. In the upper left the X-ray with the Cobb angle and SCA measurements can be seen showing high values. The upper right image shows the reductions of the same. On the lower left is the preoperative photograph of the patient and on the right, a postoperative photograph showing good balance of the shoulders.

It was observed as complications: A case of rupture of the pedicle. A case of late deep infection. A pseudarthrosis. A case of stretching of the root of $L 5$ of the concave side. A case with small loss of correction during follow-up, in the free vertebrae, between two thoracolumbar curves, one of them above $90^{\circ}$. All resolved successfully.

The surgical results were very good, with no significant loss of correction and with the absence of imbalance at the intermediate non-fixed levels, which we consider neutral vertebrae and that, in the opinion of the authors, do not require fixation. These free intermediate segments result in greater preservation of spinal mobility and better overload distribution, providing greater balance of the coronal plane.

\section{CONCLUSIONS}

We conclude that the new principle of instrumentation in the treatment of AIS and similar conditions, using short, apical and multiple fixations provides excellent correction, even better in the more distal curves in relation to the spine. There was a statistical difference in the percentages of correction of the curves from the pre- to postoperative values.

All authors declare no potential conflict of interest related to this article.

CONTRIBUTION OF THE AUTHORS: Each author made significant individual contributions to this manuscript .EBG (0000-0002-1737-7811)* was the main author. LFG (0000-0002-2425-8802)*, EBGJ (0000-0002-7612-2579)*, JGC (0000-0003-4054-0821)*, and MFC (0000-0001-9741-1727)* did the bibliographical research and prepared the article. GBP $(000-0001-6812-1245)^{\star}$, LGV $(0000-0003-2031-814 x)^{\star}$, RGG $(0000-0003-0376-8763)^{\star}$, EDU $(0000-0002-3447-0014)^{*}$, STG (0000-0002-8482-479X)*, and VOM (0000-0001-8808-4787)* reviewed the manuscript. *ORCID (Open Researcher and Contributor ID)

\section{REFERENCES}

1. Moe JH, Byrd JA. Idiopathic scoliosis. In: Lonsteins JE, Winter RB, Bradford DS RB, Olgivie JW, editors. Moe's textbook of scoliosis and other spinal deformities. 2nd ed. Philadelphia: Saunders; 1987. p. 191-232.

2. Rodrigues LMR, Yonezaki AM, Ueno FH, Nicolau RJ, Abreu LC, Filho EVS, et al.Escoliose Idiopática do Adolescente: Análise do grau de correção obtido com o uso de parafusos pediculares. Arq Bras Ciênc Saúde. 2010;35(1):1-11.

3. Brodner W, Mun Yue W, Moller HB, Hendricks KJ, Burd TA, Gaines RW. Short segment bone-on-bone instrumentation for single curve idiopathic scoliosis. Spine (Phila Pa 1976). 2003:28(20):S224-33.

4. Gaines R. Short segment bone-on-cage reconstruction for Scheuermann's kyphosis with spacers and dual rods implants. The 39th Annual Meeting of the Scoliosis Research Society on Innovative Techniques; 2004 Sep 7-9; Buenos Aires, Argentina. Milwaukee, WI: Scoliosis Research Society; 2004. p. 256

5. Garcia EB, Garcia LF, Garcia EBJr, Camarinha MF, Camarinha JG, et al. Escoliose idiopática do adolescente e similares.: Classificação Tridimensional. [PRELO].

6. Cobb J. Outline for the study of scoliosis. Instr Course Lect. 1948;5:261.

7. Garcia EB, Garcia LF, Garcia EBJr, Camarinha MF, Camarinha JG, et al. Escoliose idiopática do adolescente e similares. Nova ferramenta para mensuração global do plano coronal. [PRELO]

8. Koch GG, Landis JR, Freeman JL, Freeman DH Jr, Lehnen RC. A general methodology for the analysis of experiments with repeated measurement of categorical data. Biometrics. 1977;33(1):133-58

9. King $\mathrm{HA}$, Moe JH, Bradford DS, Winter RB. The selection of fusion levels in thoracic idiopathic scoliosis. J Bone Joint Surg Am. 1983;65(9):1302-13.

10. Lenke LG, Edwards CC 2nd, Bridwell KH. The Lenke classification of adolescent idiopathic scoliosis: how it organizes curve patterns as a template to perform selective fusions of the spine. Spine (Phila Pa 1976). 2003;28(20):S199-207.

11. Frez R, Cheng JC, Wong EM. Longitudinal changes in trunkal balance after selective fusion of King II curves in adolescent idiopathic scoliosis. Spine (Phila Pa 1976). 2000;25(11):1352-9.

12. Richards BS. Lumbar curve response in type II idiopathic scoliosis after posterior instrumentation of the thoracic curve. Spine (Phila Pa 1976). 1992;17(8 Suppl):S282-6.

13. Li M, Shen Y, Fang X, Ni J, Gu S, Zhu X, et al. Coronal and sagittal plane correction in patients with Lenke 1 adolescent idiopathic scoliosis: a comparison of consecutive versus interval pedicle screw placement. J Spinal Disord Tech. 2009:22(4):251-6.

14. Richards BS, Scaduto A, Vanderhave K, Browne R. Assessment of trunk balance in thoracic scoliosis. Spine (Phila Pa 1976). 2005;30(14):1621-6.

15. Avanzi O, Landim E, Meves R, Caffaro MFS, Umeta RSG. Adolescent idiopathic scoliosis: correlation between radiographic parameters of correction and clinical results of treatment. Coluna/Columna. 2008;7(3)201-8.

16. Oliveira GC, Cavali PTM, Landim E, Santos MAM, Lehoczki MA. Third generation instrumentation in the treatment of scoliosis in totalbody-involvement cerebral palsy patients - clinical and radiographic analysis. Coluna/Columna. 2007;6(4):201-10.

17. Naves CD, Silva LECT, Barros AGC, Aires AS, Peçanha GCA, Atencio GG. Correction of severe stiff scoliosis through extrapleural interbody release and osteotomy (LIEPO). Coluna/Columna. 2017;16(4):296-301 